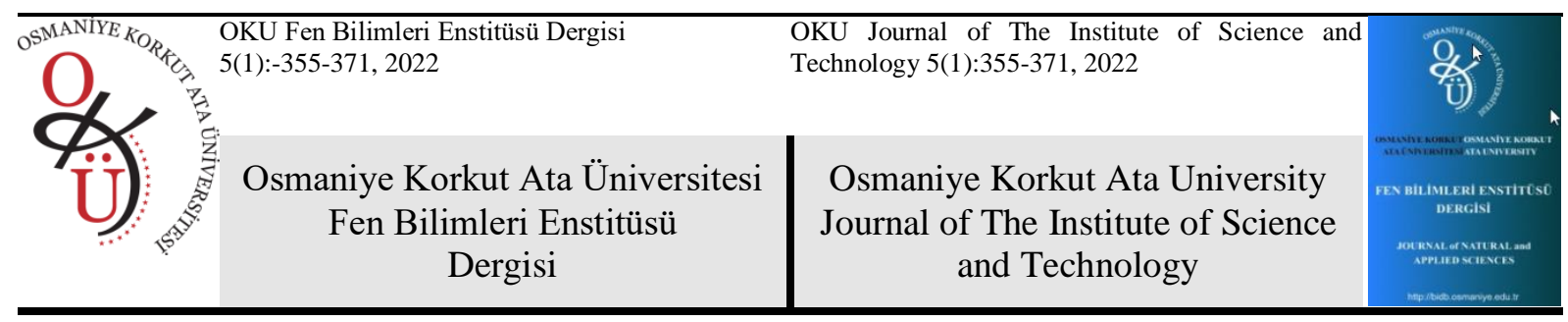

Determining the In Situ Ruminal Degradability of Some Nutrients of Wheat Straw Using Some White Rot Fungi Species

\author{
Fatma YÜKSEL ${ }^{1 *}$, Adem KAYA ${ }^{2}$ \\ ${ }^{1,2}$ Atatürk Üniversitesi, Ziraat Fakültesi, Zootekni Bölümü, 25000, ERZURUM \\ ${ }^{1}$ https://orcid.org/0000-0002-2114-1940 \\ ${ }^{2}$ https://orcid.org/0000-0002-7726-6865 \\ *Corresponding author: f.aktas7555@gmail.com
}

\section{Research Article}

\section{Article History:}

Received: 23.08.2021

Accepted: 10.02.2022

Published online:08.03.2022

\section{Keywords:}

Wheat straw,

Holstein bulls,

Phanerochaete chrysosporium,

Pleurotus eryngii,

Fungal inoculants,

In-situ degradability

\begin{abstract}
The Phanerochaete chrysosporium (PC) and Pleurotus eryngii (PE) were observed for their potential to increase the in situ dry matter (DM) and crude protein (CP) degradability of wheat straw. The wheat straw samples were inoculated with the PC and PE fungi (10\% weight/volum) and incubated under solid state fermentation conditions at $30{ }^{\circ} \mathrm{C}$ for 30 days to determine their in-situ degradability and chemical composition. In situ ruminal degradability was determined by using four ruminal cannulated Holstein bulls (approximately $400 \mathrm{~kg} \mathrm{BW}$ ) fed on a diet a concentrate-to-roughage ratio of 45:55 (dry matter (DM) basis). The samples were incubated in nylon bags for $0,4,8,16,24$, 48, 72 and $96 \mathrm{~h}$ in the rumen. The results showed that increased in situ ruminal degradation of DM and $\mathrm{CP}$ in $\mathrm{PC}$ and $\mathrm{PE}$ groups in comparison to the control group (P $<0.01)$. The wheat straw incubated with PC had the greatest in situ DM degradability after incubation for $24 \mathrm{~h}(\mathrm{P}<0.01)$. The inoculation of $\mathrm{PC}$ and $\mathrm{PE}$ increased in situ ruminal crude protein $(\mathrm{CP})$ degradation $(\mathrm{P}<0.01)$ in comparison to the other treatments. As a result, the fungal inoculants and urea treatment increased the degradability of DM and CP in wheat straw.
\end{abstract}

\title{
Siyah Alacalarda Beyaz Çürükçül Funguslar Kullanılarak Buğday Samanın In-Situ Parçalanabilirliğinin Belirlenmesi
}

\section{$\ddot{O} \mathbf{Z}$}

\begin{tabular}{l} 
Araştırma Makalesi \\
\hline Makale Tarihçesi: \\
Geliş tarihi: 23.08 .2021 \\
Kabul tarihi:10.02.2022 \\
Online Yayınlanma: 08.03.2022 \\
\hline Anahtar Kelimeler: \\
Buğday samanı, \\
Siyah Alaca \\
Phanerochaete chrysosporium, \\
Pleurotus eryngii, \\
Fungal inokulasyon \\
In-situ sindirilebilirlik
\end{tabular}

\begin{abstract}
$\mathrm{Bu}$ araştırmada, Phanerochaete chrysosporium (PC) ve Pleurotus eryngii (PE) mantar türlerinin, buğday samanının in-situ parçalanabilirliği sonucunda kuru madde $(\mathrm{KM})$ ve ham protein (HP) değerleri üzerindeki etkileri incelenmiştir. Buğday samanı örnekleri, PC ve PE fungus türleri ile (\%10 ağırlık/hacim) ile inokule edilip, in-situ parçalanabilirlikleri ve kimyasal bileşimleri belirlenmek üzere katı hal fermentasyon koşulları altında $30{ }^{\circ} \mathrm{C}^{\prime}$ de 30 gün inkübe edilmiştir. Kanül takılı 4 baş Siyah Alaca boğa (yaklaşık 400 kg canlı ağırlığa sahip) 45:55 oranında (KM esasına dayal1) konsantre / kaba yem ile beslenmiştir. Yem örnekleri rumende naylon torbalarda $0,4,8,16,24,48,72$ ve 96 saat süreyle inkübe edilmiștir. Sonuçlar, PC ve PE'nin inokulasyonunun, kontrol grubuna göre KM ve HP'nin in-situ ruminal parçalanabilirliğini yükselttiğini göstermiştir $(\mathrm{P}<0.01)$. PC ile inkübe edilen buğday samanı, 24 saat inkübasyondan sonra en yüksek in-situ KM parçalanabilirliğine sahip olmuştur $(\mathrm{P}<0.01)$. PC ve PE'nin inokulasyonu, diğer muamelelere göre in-situ rumen ham protein $(\mathrm{HP})$ parçalanabilirliğini $(\mathrm{P}<0.01)$ artırmıştır. Sonuç olarak, fungus inokulayonu ve üre muamelesinin, buğday samanındaki KM ve HP'in parçalanabilirliğini yükselttiği gözlemlenmiştir.
\end{abstract}

To Cite: Yüksel F., Kaya A. Determining the In Situ Ruminal Degradability of Some Nutrients of Wheat Straw Using Some White Rot Fungi Species. Osmaniye Korkut Ata Üniversitesi Fen Bilimleri Enstitüsü Dergisi 2022; 5(1):355-371. 


\section{Introduction}

In the world, factors such as climatic changes, rapid urbanization and socio-economic imbalances etc narrow the production areas of quality roughage and thus decrease quality roughage production. Therefore, it occurs significant nutritional problems and considerable yield losses in livestock. Improving some alternative methods to eliminate or minimize of these losses present great importance. For this aim, it is among methods the first to mind come to utilize from some food by-products having roughage characteristic. One of these by-products is wheat straw. Wheat straw, as the most abundant agricultural by-product in Turkey, is a promising alternative type of roughage variety in ruminant feeding. Although, there are some features that limit use profit of it (Jalc et al., 1997), agricultural and food industry wastes constitute a large part of the agricultural production in the world such as $30 \%$ approximately (Gültepe and Bayram, 2019).

The major limitation of using wheat straw as a feed for ruminants low rumen degradability and low energy value (Demeyer et al., 1988; Chegeni et al., 2013) due to its high lignin content (Zadrazil and Uniya, 1995). Because, cellulose and hemicellulose are hardly degraded by the rumen microorganisms (Okano et al., 2005; Turgut, 2008). To improve the disposability of wheat straw, different physical, chemical, and biological treatments were used (Brand et al., 1991; Kalkan, 2008; Turgut, 2008). The physical methods have little effect on the digestibility of this by-product (Sundstøl and Owen, 1984; Turgut, 2008). Some chemical treatments (urea, urea plus $\mathrm{Ca}(\mathrm{OH})_{2}$, urea plus $\mathrm{SO}_{2}, \mathrm{Ca}(\mathrm{OH})_{2}$ and $\mathrm{NaOH}$ plus $\mathrm{Ca}(\mathrm{OH})_{2}, \mathrm{SO}_{2}$ ) greatly improve the digestibility (Fahmy and Klopfenstein, 1994), but the application of these chemicals have poses also a high risk to the environment (Tuyen, 2012). Thus, biological methods that are believed to be more effective and more beneficial, have been earned importance recently. Because, biological methods are capable of degrading the lignocellulosic bonds and increasing the profitable of nutrients; thus, these methods can provide an economicaly and environmentally friendly alternative for chemical methods (Rahman et al., 2011). It was reported appling white rot fungi is quite effective biological method for delignification due to the fungi's a lot of characteristic (Reid, 1989; Eriksson et al., 1990). Phanerochaete chrysosporium is the model white rot fungus because of its specialized ability to degrade the abundant aromatic polymer lignin. $P$. chrysosporium releases extracellular enzymes to break up the complex three dimensional structure of lignin into components that can be utilized by its metabolism. The extracellular enzymes are nonspecific oxidizing agents (hydrogen peroxide, hydroxyl radicals) used to cleave the lignin bonds (Burdsall et al., 1974). Pleurotus eryngii belong to genus Pleurotus and are the largest species in oyster mushroom genus. Also white-rot fungicontaining this specie is reported to be able to secrete ligninolytic enzymes (lignin peroxidase (LiP), manganese peroxidase (MnP) and laccase) that are associated with ligninolyric activities (Hadibarata et al., 2012).

Little information is available on the interactions between Phanerochaete chrysosporium and Pleurotus eryngii in wheat straw, especially in terms of in situ ruminal degradability. The objective of 
our study is to investigate the effect of treatment of wheat straw with Phanerochaete chrysosporium and Pleurotus eryngii fungi species on celulose and hemicelulose degradeibility.

\section{Material and Method}

\section{The animal material and in situ process}

This study was conducted at the Eastern Anatolian Agricultural Research Institute in Erzurum, Turkey. The experiment process that approved by the Atatürk University Animal Experiments Local Ethics Committee, had conducted with decision and this decision procedures were followed throughout the experiment. Four head cannulated Holstein bulls that are 20 -month-old (average $400 \mathrm{~kg}$ BW) were used 4 weeks after the cannulation surgery. It was applied two week adaptation period before the study started. The feed ingredients and the chemical composition are showed in Table 1. In situ rumen degradation of feed and fibre components was evaluated using the nylon bag technique (Susmel et al., 1990). The samples were incubated in nylon bags for 0, 4, 8, 16, 24, 48, 72 and $96 \mathrm{~h}$ in the rumen.

\section{Preparation of feed mixtures and feeding}

The mixtures were prepared in the form of combinations reported below and each mixture was tested in two repeat in each animal. I. Wheat Straw (control), (WS); II. Wheat Straw + based on dry matter $\% 1$ Urea, (WSU); III. Wheat Straw + \%1Urea + fungi, Pleurotus eryngii (WSUPE); IV. Wheat Straw + \%1Urea+ fungi, Phanerochaete chrysosporium (WSUPC); V. Wheat Straw + fungi, Pleurotus eryngii, (WSPE); VI. Wheat Straw + fungi, Phanerochaete chrysosporium, (WSPC). The cannulated animals fed in individual paddocks were fed with 55/45 roughage / concentrate in accordance with the declarations of NRC (NRC, 1985) and clean water was kept in front of the animals.

\section{Microorganisim, chemical and fungal inoculant preparation}

In this study two fungi varietes and urea were used. Phanerochaete chrysosporium (NRRL 6370) was obtained from the ARS Culture Collection, USDA, USA. Pleurotus eryngii was purchased from a commercial company and reproduced in the laboratory of Biology Department of the Faculty of Science of Atatürk University. In feed mixture groups, it was used 1\% ratio from granular urea obtained by heating ammonium carbonate to $150-200{ }^{\circ} \mathrm{C}$. The dried wheat straw was weighed to $750 \mathrm{~g}$ at autoclave resistant plastic bags. In order to have a moisture content of $60 \%$ was added distilled water to the straw sachets before from biological degradation. Moisture content of urea added straw samples was provided by adding dissolving in water of urea. Then the bags were closed and sterilized at $121{ }^{\circ} \mathrm{C}, 1 \mathrm{~atm}$ pressure for 15 minutes. To sterile straws prepare to solid state fermentation were inoculated solition at a rate of $10 \%(\mathrm{w} / \mathrm{v})$ and achieved under aseptic conditions homogeneity. Then the straw samples were allowed to incubation in the incubator at $30{ }^{\circ} \mathrm{C}$ for 30 days. 


\section{Chemical component analysis}

The DM content was measured by drying samples in an electrical oven at $105^{\circ} \mathrm{C}$ for $2 \mathrm{~h}$ (AOAC, 1990). The ash content was measured by burning the samples in a electrical furnace at $550{ }^{\circ} \mathrm{C}$ for $4 \mathrm{~h}$ (AOAC, 1990). Nitrogen (by Kjeldalh metod) and ether extract (by Soxhleth device) were measured according to AOAC (AOAC, 1990). Acid detergent fibre (ADF), neutral detergent fibre (NDF) and acid detergent lignin (ADL) were measured according to the procedure recommended by Van Soest et al. (1991). The hemicellulose content was estimated by the difference between NDF and ADF, and the cellulose content was calculated based on the difference between ADF and ADL. The hemicellulose content was estimated by the difference between NDF and ADF, and the cellulose content was calculated based on the difference between ADF and ADL. The OM was measured as the difference between DM and the ash content. The component degradation ratio was calculated on the basis of the total component weight loss after pretreatment (Ma et al., 2011). Using 48 hours dry matter degradability values of roughages, metabolic energy values were determined by using the regression equation $(\mathrm{ME},(\mathrm{Mj} / \mathrm{kg} \mathrm{DM})=2.27563+0.1073 * \mathrm{KMP})$ developed at Rowett Research Institute (Karabulut and Canbolat, 2005).

\section{Chemical analysis of feeds}

Table 1. Chemical composition of feed ingredients used in the study

\begin{tabular}{|c|c|c|c|c|c|c|}
\hline \multirow[t]{2}{*}{ Feeds } & \multicolumn{4}{|c|}{ Components (\%) } & \multirow[b]{2}{*}{$\mathrm{NDF}$} & \multirow[b]{2}{*}{$\mathrm{ME}(\mathrm{Kcal} / \mathrm{kg})$} \\
\hline & $\mathrm{DM}$ & $\mathrm{CP}$ & $\mathrm{CA}$ & $\mathrm{ADF}$ & & \\
\hline Concentrate & 88.2 & 16.0 & 7.1 & - & - & 2500 \\
\hline Dry meadow grass & 88.1 & 10.7 & 8.5 & 39.0 & 64.3 & 2100 \\
\hline Dry clover & 88.7 & 19.1 & 8.5 & 31.0 & 40.0 & 2100 \\
\hline Wheat straw & 91.6 & 3.81 & 7.8 & 49.4 & 73.0 & 1480 \\
\hline
\end{tabular}

\section{Formulations for degradability ratios}

DM and CP degradability after incubation was calculated according to the following formulas (Susmel et al., 1990).

DM (degradability \%)=[[((W1-W4) * DM\%) - ((W3-W2)*100)]/(W1-W4)*DM\%]*100

$\mathrm{W} 1=$ sample weight.W2=weight of empty bag in desiccator. W3=dried weight of bags taken from rumen at 70 degrees for 24 hours. W4= weight of sample evacuated bag outside 24 hours

$\mathrm{CP}($ degradability $\%)=[(\mathrm{Y} 1-\mathrm{Y} 2) / \mathrm{Y} 1]^{*} 100$

$\mathrm{Y} 1=$ amount of crude protein before incubation. $\mathrm{Y} 2=$ amount of crude protein after incubation 
Variables of in situ degradation rapidit of feed samples were estimated according to the following model (Ørskov and McDonald 1979; McDonald, 1981; Susmel et al., 1990; Ribeiro, 1994).

Model D.\% $=\mathrm{a}+\mathrm{b} \times[1-\exp (-\mathrm{ct})]$

where $\mathrm{D}=$ degraded proportion at time $\mathrm{t} ; \mathrm{a}=$ the fraction that immediately disappears from the bag; $\mathrm{b}$ $=\mathrm{N}$ loss due to microbial activity in rumen; $\mathrm{c}=$ constant rate of degradation of fraction $\mathrm{b}(\mathrm{h}-1)$; and $\mathrm{t}$ $=$ incubation time $(\mathrm{h})$.

The effective degradability (ED) was calculated using the following equation:

Effective $D=a+b[b c /(c+k](1-e-(c+k) t)$

where a: fast dissolution and degradation in rumen for nutrients. b: potential degradability value that requires a certain time to dissolve and degrade. c: from rumen passage rate that is assumed as $0.02 / \mathrm{h} . \mathrm{t}$ is degradation time. $\mathrm{k}$ is flow rate from rumen.

The chemical composition components such as DM, CP, CA, NDF, ADF, ADL, OM, cellulose, hemi cellulose and the ruminal parameters such as a, b, c and $\mathrm{k}$ were analysed using analysis of variance (ANOVA). Between treatment and incubation time had on the in situ degradability parameters were analysed using the univariate tests that are part of general linear model analysis. In this process, the following mathematical model was applied.

$Y i j k=\mu+a_{i}+b_{j}+(a b)_{i j}+e_{i j k}$

Where. $\mu$ : mean of the sample. ai: the effect of treatment. bj: the effect of incubation times. eijk: error.

The statistical analyses were performed with the statistical software package SPSS 20.0 (SPSS. 2010).

\section{Results}

\section{Changes in chemical composition}

The chemical analysis of the feed mixtures are given in Table 2. All of the fungal treatments (except WSPC) and urea treatment reduced the DM, OM, hemicellulose, cellulose, NDF, ADF and ADL content of the wheat straw after 30 days of fermentation $(\mathrm{P}<0.01)$. On the other hand, it was higher $\mathrm{CP}$ and crude fat according to the control.

The wheat straw incubated with Pleurotus eryngii + urea had the lowest DM, OM, NDF, ADL and hemicellulose content $(\mathrm{P}<0.01)$, but the highest $\mathrm{CP}$, cellulose and ash content $(\mathrm{P}<0.01)$ in comparison to the other treatments. The wheat straw incubated with Pleurotus eryngii + urea had the lowest DM, OM, NDF, ADL and hemicellulose content $(\mathrm{P}<0.05)$, but the highest for $\mathrm{CP}$, cellulose and $\mathrm{CA}$ content $(\mathrm{P}<0.05)$ in comparison to the other treatments. The DM and OM contents in the wheat straw inoculated with Phanerochaete chrysosporium fungi were higher than WS treatment $(\mathrm{P}<$ 0.01), were similar in point of hemicellulose and crude ash (Table 2). 
Table 2. Chemical composition of wheat straw incubated with the Phanerochaete chrysosporium. Pleurotus eryngii Fungus. urea for 30 days $(\%)$

\begin{tabular}{|c|c|c|c|c|c|c|c|c|c|c|}
\hline \multirow[b]{2}{*}{ Feed Mixture Groups } & \multicolumn{10}{|c|}{$\operatorname{Variables}(\%)(\overline{\mathbf{X}} \pm \mathbf{S} \overline{\mathbf{x}})$} \\
\hline & DM & $\mathbf{O M}$ & $\mathbf{C P}$ & EE & $\mathbf{H C}$ & ADF & NDF & ADL & $\mathbf{C}$ & $\mathbf{C A}$ \\
\hline & $* *$ & $* *$ & $* *$ & $* *$ & $* *$ & $* *$ & $* *$ & $* *$ & $* *$ & $* *$ \\
\hline WSPC & $92.67^{\mathrm{a}}$ & $85.32^{\mathrm{a}}$ & $10.31^{\mathrm{c}}$ & $3.50^{\mathrm{b}}$ & $27.03^{\mathrm{a}}$ & $33.50^{\mathrm{c}}$ & $60.53^{\mathrm{c}}$ & $7.92^{\mathrm{bc}}$ & $25.57^{\mathrm{bc}}$ & $7.34^{\mathrm{bc}}$ \\
\hline WSUPC & $89.00^{\mathrm{c}}$ & $81.95^{\mathrm{c}}$ & $11.80^{\mathrm{b}}$ & $4.76^{\mathrm{a}}$ & $25.79^{\mathrm{a}}$ & $31.38^{\mathrm{d}}$ & $57.17^{\mathrm{d}}$ & $9.43^{\mathrm{b}}$ & $24.55^{\mathrm{c}}$ & $7.04^{\mathrm{c}}$ \\
\hline WSPE & $89.63^{\mathrm{c}}$ & $80.60^{c}$ & $8.86^{\mathrm{d}}$ & $2.58^{\mathrm{cd}}$ & $20.04^{\mathrm{b}}$ & $34.69^{\mathrm{c}}$ & $54.74^{\mathrm{e}}$ & $7.25^{\mathrm{c}}$ & $27.44^{\mathrm{b}}$ & $9.02^{\mathrm{a}}$ \\
\hline WSUPE & $87.43^{\mathrm{d}}$ & $78.36^{\mathrm{d}}$ & $16.66^{\mathrm{a}}$ & $2.87^{\mathrm{c}}$ & $15.90^{\mathrm{c}}$ & $38.66^{\mathrm{b}}$ & $54.57^{\mathrm{e}}$ & $6.63^{\mathrm{c}}$ & $32.03^{\mathrm{a}}$ & $9.07^{\mathrm{a}}$ \\
\hline WSU & $88.93^{\mathrm{c}}$ & $81.13^{c}$ & $10.93^{\mathrm{bc}}$ & $2.19^{\mathrm{d}}$ & $25.51^{\mathrm{a}}$ & $41.98^{\mathrm{a}}$ & $67.49^{\mathrm{b}}$ & $11.31^{\mathrm{a}}$ & $30.66^{\mathrm{a}}$ & $7.80^{\mathrm{bc}}$ \\
\hline WS (control) & $91.61^{\mathrm{b}}$ & $83.62^{b}$ & $3.81^{\mathrm{e}}$ & $2.11^{\mathrm{d}}$ & $27.03^{\mathrm{a}}$ & $42.77^{\mathrm{a}}$ & $70.94^{\mathrm{a}}$ & $11.71^{\mathrm{a}}$ & $31.06^{\mathrm{a}}$ & $7.99^{\mathrm{b}}$ \\
\hline SEM & \pm 0.29 & \pm 0.456 & \pm 0.40 & \pm 0.18 & \pm 0.86 & \pm 0.53 & \pm 0.56 & \pm 0.52 & \pm 0.83 & \pm 0.26 \\
\hline
\end{tabular}

DM: dry matter; OM: organic matter; CP: crude protein; EE: ether extract; HC: hemicellulose; ADF: acid detergent fiber; NDF: neutral detergent fiber. ADL: acid detergent lignin. C: cellulose; CA: crude ash; WSPC: wheat straw + Phanerochaete chrysosporium; WSUPC: wheat straw + urea + Phanerochaete chrysosporium; WSPE: wheat straw + Pleurotus eryngii; WSUPE: wheat straw + urea + Pleurotus eryngii; WSU: wheat straw + urea; WS: wheat straw; SEM: standard error of the mean. **: $\mathrm{P}<0.01$; a-e: means in the same column with different letters differ 


\section{In situ degradability}

In the study in situ DM and crude protein degradation values (\%) determined according to feed mixture groups and at different rumen incubation times are given in Table 3. Differences were found among the different treatments and incubation times for in situ degradation of DM; differences in the degradation of this component was observed significant $(\mathrm{P}<0.01)$. The Pleurotus eryngii + wheat straw (WSPE) treatment had the highest DM degradability after $0 \mathrm{~h}$ and $4 \mathrm{~h}$ than other mixture groups. Wheat straw + Pleurotus eryngii (WSPE). Wheat straw + Phanerochaete chrysosporium (WSPC) and wheat straw + urea + Phanerochaete chrysosporium (WSUPC) mixture groups was found similar insitu DM degradation after $8 \mathrm{~h}$ and $16 \mathrm{~h}$, and these groups were higher than the other groups, including the control group $(\mathrm{P}<0.01)$. In incubations after 24 hours was seen a certain degree effect superiority of PC adding mixtures. The in situ ruminal degradation of DM was higher in the WSPC and WSUPC mixtures than other all groups after $24 \mathrm{~h}$, and a similar result was observed in the results after $72 \mathrm{~h}(\mathrm{P}$ $<0.01)$. The WSUPE, WSPC and WSUPC treatments had the highest DM degradability after $48 \mathrm{~h}$ and $96 \mathrm{~h}$.

Feed mixture groups affected CP disappearances as a function of incubation time and differences for $\mathrm{CP}$ disappearance between treatments groups at all rumen incubation times were observed $(\mathrm{P}<0.01$, table 3). The highest degradation rate of wheat straw was observed with the WSPE, which achieved a $9.61 \%, 17.62 \%$ respectively loss of crude protein after $0 \mathrm{~h}$ and $4 \mathrm{~h}$ incubation. In the losses of crude protein observed after $0 \mathrm{~h}$. WSUPE with WSUPC, and WSPC with WSU were similar, and the lowest degradation rate was achieved with the WS. The four feed mixtures (WSUPE, WSUPC, WSPE, WSPC), to degradation of crude protein showed the highest proportionate loss after incubation $8 \mathrm{~h}$. The other two feed mixtures (WS, WSU) showed the lowest proportionate loss in crude protein prodegradability. The WSPE and WSUPC treatments had the highest CP ruminal degradation after 16 $\mathrm{h}(\mathrm{P}<0.01)$. The in-situ ruminal degradation of $\mathrm{CP}$ was higher $(\mathrm{P}<0.01)$ in the WSUPC mixture than other all groups after $24 \mathrm{~h}$, and was similar ( $\mathrm{P}>0.05$ ) one another WSUPE, WSPE and WSPC. On the other hand, observed the lowest degradation value in WS group. Including different fungis and urea the four feed mixtures (WSUPE, WSUPC, WSPE, WSPC), for crude protein showed the highest degradation after incubation $48 \mathrm{~h}$. The WSUPE feed mixture showed peak crude protein degradation in ruminal incubation after $72 \mathrm{~h}$ and $96 \mathrm{~h}(80.32 \%, 90.82 \%$ respectively), which were higher $(\mathrm{P}<$ 0.01 ) than the corresponding findings for the P. chrysosporium + urea treatment and other groups. 
Table 3. Effect of mushroom inoculation and urea treatment on dry matter and crude protein rumen degradability at the end of the incubation times. Incubation times (hour)

\begin{tabular}{|c|c|c|c|c|c|c|c|c|c|c|c|c|c|c|c|c|}
\hline \multirow{2}{*}{$\begin{array}{l}\text { Feed } \\
\text { Mixture } \\
\text { Groups }\end{array}$} & \multicolumn{2}{|c|}{$\mathbf{0}$} & \multicolumn{2}{|c|}{4} & \multicolumn{2}{|c|}{8} & \multicolumn{2}{|c|}{16} & \multicolumn{2}{|c|}{24} & \multicolumn{2}{|c|}{48} & \multicolumn{2}{|c|}{72} & \multicolumn{2}{|c|}{96} \\
\hline & DM & $\mathrm{CP}$ & DM & $\mathrm{CP}$ & DM & $\mathrm{CP}$ & $\mathrm{DM}$ & $\mathrm{CP}$ & DM & $\mathrm{CP}$ & DM & $\mathrm{CP}$ & DM & $\mathrm{CP}$ & DM & $\mathrm{CP}$ \\
\hline & $* *$ & $* *$ & $* *$ & $* *$ & $* *$ & $* *$ & $* *$ & $* *$ & $* *$ & $* *$ & $* *$ & $* *$ & $* *$ & $* *$ & $* *$ & $* *$ \\
\hline WSPE & $11.22^{\mathrm{a}}$ & $9.61^{\mathrm{a}}$ & $18.46^{\mathrm{a}}$ & $17.62^{\mathrm{a}}$ & $26.23^{\mathrm{a}}$ & $24.62^{\mathrm{a}}$ & $34.42^{\mathrm{a}}$ & $35.60^{\mathrm{a}}$ & $41.02^{\mathrm{c}}$ & $43.79^{\mathrm{b}}$ & $57.71^{\mathrm{b}}$ & $65.21^{\mathrm{a}}$ & $70.59^{\mathrm{b}}$ & $75.41^{\mathrm{c}}$ & $76.44^{\mathrm{ab}}$ & $84.31^{\mathrm{c}}$ \\
\hline WSUPE & $9.69^{\mathrm{b}}$ & $8.63^{b}$ & $15.91^{\mathrm{b}}$ & $14.88^{\mathrm{bc}}$ & $24.31^{\mathrm{ab}}$ & $25.53^{\mathrm{a}}$ & $33.62^{\mathrm{a}}$ & $33.86^{\mathrm{b}}$ & $42.68^{\mathrm{bc}}$ & $44.37^{\mathrm{b}}$ & $62.35^{\mathrm{a}}$ & $66.47^{\mathrm{a}}$ & $70.71^{\mathrm{b}}$ & $80.32^{\mathrm{a}}$ & $79.24^{\mathrm{a}}$ & $90.82^{\mathrm{a}}$ \\
\hline WSPC & $7.99^{c}$ & $6.72^{c}$ & $15.32^{\mathrm{b}}$ & $13.86^{\mathrm{cd}}$ & $26.13^{\mathrm{a}}$ & $24.77^{\mathrm{a}}$ & $34.30^{\mathrm{a}}$ & $32.85^{\mathrm{b}}$ & $46.32^{\mathrm{a}}$ & $44.19^{\mathrm{b}}$ & $63.25^{\mathrm{a}}$ & $65.11^{\mathrm{a}}$ & $72.61^{\mathrm{a}}$ & $75.33^{\mathrm{c}}$ & $77.45^{\mathrm{a}}$ & $82.86^{\mathrm{c}}$ \\
\hline WSUPC & $8.29^{c}$ & $8.70^{\mathrm{b}}$ & $15.83^{\mathrm{b}}$ & $15.36^{\mathrm{b}}$ & $25.82^{\mathrm{a}}$ & $25.54^{\mathrm{a}}$ & $33.90^{\mathrm{a}}$ & $35.78^{\mathrm{a}}$ & $44.54^{\mathrm{ab}}$ & $45.96^{\mathrm{a}}$ & $62.22^{\mathrm{a}}$ & $65.58^{\mathrm{a}}$ & $72.43^{\mathrm{a}}$ & $78.49^{\mathrm{b}}$ & $78.67^{\mathrm{a}}$ & $88.11^{b}$ \\
\hline WSU & $8.62^{\mathrm{bc}}$ & $7.54^{\mathrm{c}}$ & $14.51^{\mathrm{bc}}$ & $13.23^{\mathrm{d}}$ & $22.91^{\mathrm{b}}$ & $22.33^{\mathrm{b}}$ & $30.35^{\mathrm{b}}$ & $29.70^{\mathrm{c}}$ & $38.34^{\mathrm{d}}$ & $38.56^{\mathrm{c}}$ & $54.24^{\mathrm{c}}$ & $55.67^{\mathrm{b}}$ & $67.59^{c}$ & $69.37^{\mathrm{d}}$ & $74.10^{\mathrm{bc}}$ & $76.09^{\mathrm{d}}$ \\
\hline WS (c) & $7.62^{\mathrm{c}}$ & $5.44^{\mathrm{d}}$ & $12.99^{\mathrm{c}}$ & $9.46^{\mathrm{e}}$ & $19.76^{\mathrm{c}}$ & $15.46^{\mathrm{c}}$ & $26.86^{\mathrm{c}}$ & $24.80^{\mathrm{d}}$ & $34.01^{\mathrm{e}}$ & $32.55^{\mathrm{d}}$ & $49.64^{\mathrm{d}}$ & $50.16^{\mathrm{c}}$ & $62.41^{\mathrm{d}}$ & $63.38^{\mathrm{e}}$ & $71.80^{\mathrm{c}}$ & $71.85^{\mathrm{e}}$ \\
\hline SEM & \pm 0.39 & \pm 0.29 & \pm 0.64 & \pm 0.44 & \pm 0.79 & \pm 0.56 & \pm 0.58 & \pm 0.59 & \pm 0.76 & \pm 0.50 & \pm 0.76 & \pm 0.85 & \pm 0.57 & \pm 0.59 & \pm 0.97 & \pm 0.71 \\
\hline
\end{tabular}

DM: dry matter; CP: crude protein; WSPC: wheat straw + Phanerochaete chrysosporium; WSUPC: wheat straw + urea + Phanerochaete chrysosporium; WSPE: wheat straw + Pleurotus eryngii; WSUPE: wheat straw + urea + Pleurotus eryngii; WSU: wheat straw + urea; WS: wheat straw; c: control; SEM: standard error of the mean. **: P<0.01; a-e: means in the same column with different letters differ 


\section{In situ degradability parameters}

Statistically analysis of in-situ degradation parameters for DM and CP in the study is presented in Table 4. Differences were found significant $(\mathrm{P}<0.01)$ among the different treatments "a" parameter for DM. The "a" parameter was higher in WSPE group than other feed mixture groups and other groups were similar one another statistically. Not significant differences were observed the ' $b$ ' fraction for DM in the different treatments (Table 4). Rumen passage rate of DM fraction 'c' varied among feed mixtures groups, and the ' $c$ ' value for DM in WSPC was higher $(\mathrm{P}<0.01)$ than other groups (Table 4). The lowest passage rate value DM fraction was obtained from WS (control) group. Significant differences were observed among the treatment groups in terms of the ' $\mathrm{k}$ ' fraction. WSUPE, WSPC, WSUPC feed mixture groups were the highest DM fraction ' $k$ ' parameter value.

Differences were found among the different treatments for in-situ ruminal degradation of CP; the differences in the ruminal degradation of those parameters were similar partially with findings of DM in terms of interaction among groups. The in situ ruminal degradation of ' $\mathrm{a}$ ' fraction for $\mathrm{CP}$ was higher in WSPE group than other feed mixture groups. As to the ' $b$ ' fraction was the highest in the WSUPE group. Results of the study revealed that in feed mixture groups, uninoculed and inoculed wheat straw have rumen passage rate fraction (c) 0.01 to 0.02 for CP degradability. WSPE, WSPC, WSUPC and WSU groups were similar statistically and had the highest ' $c$ ' fraction value. There was significant difference among other groups of treatments with these groups $(\mathrm{P}<0.01)$. The "k" fraction was the highest in WSUPE group for CP degradability. 
Table 4. Effect of mushroom inoculation and urea treatment on dry matter and crude protein degradability parameters at the end of the incubation times.

\begin{tabular}{|c|c|c|c|c|c|c|c|c|}
\hline \multirow{3}{*}{ Feed Mixture Groups } & \multicolumn{8}{|c|}{ Degradability parameters } \\
\hline & \multicolumn{2}{|c|}{ a $(\%)$} & \multicolumn{2}{|c|}{ b (\%) } & \multicolumn{2}{|c|}{ c $(1 / h)$} & \multicolumn{2}{|c|}{ k 0.05/h } \\
\hline & $\mathrm{DM}$ & $\mathrm{CP}$ & $\mathrm{DM}$ & $\mathrm{CP}$ & DM & $\mathrm{CP}$ & DM & $\mathrm{CP}$ \\
\hline & $* *$ & $* *$ & ns & $* *$ & $* *$ & $* *$ & $* *$ & $* *$ \\
\hline WSPE & $12.66^{\mathrm{a}}$ & $10.37^{\mathrm{a}}$ & 75.08 & $83.59^{\mathrm{bc}}$ & $0.021^{\mathrm{ab}}$ & $0.02^{\mathrm{a}}$ & $63.15^{\mathrm{b}}$ & $63.68^{\mathrm{c}}$ \\
\hline WSUPE & $9.82^{\mathrm{b}}$ & $9.25^{\mathrm{ab}}$ & 77.25 & $97.25^{\mathrm{a}}$ & $0.024^{\mathrm{ab}}$ & $0.01^{\mathrm{b}}$ & $63.31^{\mathrm{a}}$ & $64.0^{\mathrm{a}}$ \\
\hline WSPC & $8.19^{b}$ & $7.15^{\mathrm{c}}$ & 73.51 & $83.25^{\mathrm{bc}}$ & $0.030^{\mathrm{a}}$ & $0.02^{\mathrm{a}}$ & $63.40^{\mathrm{a}}$ & $63.62^{\mathrm{c}}$ \\
\hline WSUPC & $9.07^{\mathrm{b}}$ & $9.33^{\mathrm{ab}}$ & 75.24 & $88.75^{\mathrm{b}}$ & $0.026^{\mathrm{ab}}$ & $0.02^{\mathrm{a}}$ & $63.37^{\mathrm{a}}$ & $63.96^{\mathrm{b}}$ \\
\hline WSU & $9.60^{\mathrm{b}}$ & $8.34^{\mathrm{b}}$ & 77.02 & $81.69^{c}$ & $0.020^{\mathrm{ab}}$ & $0.02^{\mathrm{a}}$ & $62.98^{\mathrm{c}}$ & $63.08^{\mathrm{d}}$ \\
\hline WS (c) & $7.80^{\mathrm{b}}$ & $5.06^{\mathrm{d}}$ & 82.10 & $85.55^{\mathrm{bc}}$ & $0.015^{\mathrm{b}}$ & $0.01^{\mathrm{b}}$ & $62.86^{\mathrm{c}}$ & $62.87^{\mathrm{e}}$ \\
\hline SEM & \pm 3.65 & \pm 0.37 & \pm 2.31 & \pm 2.01 & \pm 0.001 & \pm 0.001 & \pm 0.047 & \pm 0.034 \\
\hline
\end{tabular}

a: fast dissolution and degradation in rumen for nutrients. b: potential degradability value that requires a certain time to dissolve and degrade. c: from rumen passage rate that is assumed as $0.02 / \mathrm{h}$. $\mathrm{t}$ is degradation time. $\mathrm{k}$ is flow rate from rumen. DM: dry matter; CP: crude protein; WSPC: wheat straw + Phanerochaete chrysosporium; WSUPC: wheat straw + urea + Phanerochaete chrysosporium; WSPE: wheat straw + Pleurotus eryngii; WSUPE: wheat straw + urea + Pleurotus eryngii; WSU: wheat straw + urea; WS: wheat straw; c: control; SEM: standard error of the mean. **: $\mathrm{P}<0.01$; ns: no significant; a-e: means in the same column with different letters differ 


\section{Discussion}

In the present study, the WSPC treatment had a higher value in terms of DM content after $30 \mathrm{~d}$ incubation than the other treatment groups. It was determined which was in agreement with the founding of those Karimi et al. (2014) (untreated rice straw), Shrivastava et al., (2011), Denek and Deniz (2004). But it was indicated more high findings by Kutlu et al., (2000) and more low findings (maize stalk) by Tao et al., (2016). The high ratio of DM in WSPC treatment group can probably explained by the fact that some fungis behave according to the acidic, alkaline or neutral environment of the environment and may affect the water retention and weight losses of the material they are inoculated (Talaei et al., 2013). Thus, they react to heat treatment differently. Because of these properties, they are thought to maintain the bound moisture of the material in which they are inoculated and thus prevent weight loss (Talaei et al., 2013). In the present study in chemical analysis, dry matter content of urea added mixtures (WSUPC, WSUPE) was showed lower than the form (WSPC, WSPE) without urea of the same mixture group. This situation was thought to be caused the fungi to increase of nutrient losses in urea added environment. Thus, it was reported that the loss of dry matter in fungal processes results from increase of consumption of carbohydrates by the fungi (Shrivastava et al., 2011; Chaturvedi and Verme 2013; Sharma and Arora 2013).

The WSUPE group had the highest crude protein content among the feed mixture groups. This result determined in the present study had a higher value than from results reported by Jalc et al., (1997), Karimi et al., (2014) and Kutlu et al., (2000) which carred out urea molasses treated rice straw. Fungal inoculation had been reported to increase protein content (Zadrazil and Uniya, 1995). However, it is possible to encounter different results. Crude protein content was higher in fungal and urea added mixtures (WSPC, WSUPC, WSPE, WSU) than control group. This result agreed with finding reported by Jalc et al., (1997).

In this present study, the hemicellulose, ADF, NDF, ADL and cellulose content of the WSU and WS treatment groups had peaks generally (except WSU for NDF, inclusive WSUPE for cellulose). Yao and Nokes (2014) and Singh et al., (2011) investigated wheat straw treated with P. chrysosporium and showed a significant drop in this cell wall components comparison to the untreated straw after incubation. The levels of ADF in the all mixture feed groups were also lower in comparison to results reported by Jalc et al., (1997) and Adamovic et al., (1998). On the other hand, the NDF (Jalc et al., 1997) and cellulose (Adamovic et al., 1998) values of the mixture groups obtained by inoculating the fungi to straw found lower from results of different studies. Similar effects on the hemicellulose value of wheat straw were presented by (Adamovic et al., 1998). Fungal treatment significantly reduced the concentration of the cellwall components (NDF, hemicellulose) using the fungi PE and (ADF, cellulose) using the fungi PC.

The results with respect to in initial incubation times (until $16 \mathrm{~h}$ ) dry matter degradability in rumen showed that without urea treatment. PE fungi inoculation had significant effects on initial dry matter degradability. Urea adding treatment increased partially initial dry matter degradability in this 
incubation times. Although PC fungi inoculation did not affect in high ratio dry matter degradability in urea treated straw in initial incubation times, inlater incubation times (after $24 \mathrm{~h}$ ) increased dry matter degradability. This stuation is mainly a reflection of action of fungi in the alkali condition in urea treated straw. Dry matter degradation in rumen increased with urea treatment. fungi inoculation and the increase in the incubation times. After 24 hours rumen incubation, it was observed that was affect of WSPC and WSUPC groups high degradability in rumen in term of dry matter in 48, 72 and $96 \mathrm{~h}$. Similarly, Kutlu et al., (2000) reported that dry matter degradation rates of treatment groups at 24, 48, 72 and $96 \mathrm{~h}$ was affected by the urea treatment, mushroom inoculation, the time after mushroom inoculation and urea $\mathrm{x}$ mushroom interaction. Likewise it was stated increased rumen degradability with incubation time (Moon et al., 2010), degraded approximately 25\% (Yildırım and Yildı, 2010) and $80 \%$ (Valmaseda et al., 1990) of DM by PE fungi. On the other hand, there were no significant differences between untreated and treated rice straw in terms of DM and NDF degradability was reported by Karimi et al., (2014). Also, it was indicated straw treated with PE fungus showed the lowest degradability at 48 th, 72 th and at 96 th h of incubation (Fazaeli et al., 2004).

In the study, rapidly soluble DM fraction (a) varied among feed mixture groups. and the 'a' value for DM in WSPE group was higher both numerical and statistical than other forages (Table 3). The lowest rapidly degradable DM fraction was obtained, not statistical but numerical, from WS (control) group. The average rapidly soluble DM fraction for all feed mixture groups in this study was lower than the findings reported by Turgut and Yanar (2004) for some forages and by Karimi et al., (2014) for treated rice straw. But, the average 'a' value for all feed mixture groups in this study was higher generally than findings of Tao et al., (2016) and Karimi et al., (2014) determined for untreated rice straw. These discrepancies may be attributed to content of the feed mixture groups and substrat differences in the studies.

Although the potential degradability fraction ' $b$ ' values for DM were not significant among groups statistically, it was observed difference at a certain rate among mixture groups (Table 4). The degradable DM fraction value of 'b' for different substrat reported by Tao et al., (2016), Karimi et al., (2014) and Turgut and Yanar (2004) were lower than the 'b' fraction value obtained in the present study.

The rumen passage rate of DM degradation (c value) in the feed mixture groups were high in groups treated with urea and fungi, Karimi et al., (2014) was determined similar reseults in untreated rice straw and urea molasses treated rice straw groups. The higher results were obtained by Turgut and Yanar (2004) who reported 'c' values for different forages. Tao et al., (2016) found partly lower values for the 'c' fraction in cell-wall components in the maize stalk according to this research findings.

Significant differences were observed among feed mixture groups studied with respect to effective degradabilities of DM. The result was in accordance statistically with finding of Tao et al., (2016) and Turgut and Yanar (2004) but were the higher numerically from results of these two studies. 
In the study, the crude protein content was significantly increased by fungal inoculation and urea treatment and this increase had changed accorgin to fungi varieties. Urea treatment and incubation times. In initial incubation times (until $8 \mathrm{~h}$ ) crude protein degradability in rumen showed that without urea treatment. PE fungi inoculation had obvious effects on initial crude protein degradability. It was no significant difference among the groups until the 8 th hour but after from 16 th hour this interaction began to become clear. At the 16 th hour, the WSUPC group showed high protein degradability associated with WSPE group. Similar situation was observed at 24 hours as well. Crude protein degradability found higher in groups that treated fungi and urea both statistically and numerically at 48 th hour. Similarly, at 72 th and 96 th hours, the fungus and urea treated groups had high protein degradability and PE fungus was found to be more effective, especially in the urea-treated environment. The assumption increase of protein content by fungal inoculation is one of hypothesis of this study. This hypothesis is supported by Tuyen et al., (2012) and Zadrazil and Uniya (1995). Similar to our results, Turgut and Yanar (2004) found that incubation times increased the CP gain in different forages.

Effect of the feed mixture groups on the degradation rate all the parameters of the $\mathrm{CP}(\mathrm{a}, \mathrm{b}, \mathrm{c}, \mathrm{k})$ was appearance similar with DM degradation. Although the mixture groups inoculed with PE had the higher ' $a$ ' value in initial of incubation in this study, inoculed groups with PC had showed similar effect in the forthcoming days. Means of 'a' for all feed mixture groups were lower than findings of Turgut and Yanar (Turgut and Yanar, 2004) who determined degrdation parameters for CP in some forages. However. the "b" parameter value determined for CP in this study were found to be lower than our results. Besides, Tao et al., (2016) showed that the PC types of white rot fungi increased the ' $a$ ' and ' $b$ ' parameters value of maize stalk in comparison to without fungi inoculants. In the present study, the results determined for the "a" parameter were higher than the findings indicated by Tao et al., (2016) and the lower ' $b$ ' parameter. The differences in both ' $a$ ' and ' $b$ ' CP values may be as a result of differences in fungus variete, urea treatment, incubation times on wheat straw. The parameter ' $c$ ' followed a close course among the feed mixture groups. The parameter ' $k$ ' followed a diferrent course among the feed mixture groups. Similarly, Tao et al., (2016) investigated maize stalk treated with $P$. chrysosporium and showed a significant different (decrease) in the content of without fungus in comparisonto the untreated straw after incubation.

\section{Conclusions}

Results of this study suggest that fungal inoculation and urea treatment are promising means to convert low-quality wheat straw into a higher quality ruminant feed. The inoculantion of PC, PE and urea treatment the greater effect on improving the ruminal degradability of DM and CP. The degradation of the DM in wheat straw was altered significantly, mainly by the fungi PC. This fungus can be used in wheat straw for husbandry. 


\section{Acknowledgement}

This work was supported by funds of the Turkey Agriculture and Forest Ministry. General Directorate of Agricultural Research and Policies and Eastern Anatolian Agricultural Research Intitute.

\section{Conflict of interest}

The authors acknowledge that this study is a Ph.D thesis. The authors declared that there is no conflict of interest.

\section{Author's Contributions}

The contribution of the authors is equal.

\section{References}

AOAC. Official Methods of Analysis. 15th ed. Association of Official Analytical Chemists. Arlington. Virginia 1990.

Brand AA., Clcete SWP., Franck F. The effect of supplementing untreated. urea-supplemented and urea-ammoniated wheat-straw with maize-meal and/or fish-meal in sheep. S.Afr. Tydskr. Veek 1991; 21(1): 48-54.

Burdsall HH., Jr H., Eslyn W. A new Phanerochaete with Chrysosporium imperfect state. Mycotaxon 1974; $1: 124$.

Chaturvedi V., Verme P. An overview of key pretreatment processes employed for bioconversion of lignocellulosic biomass into biofuels and value added products. 3 Biotech 2013; 3: 415-431.

Chegeni A., Li YL., Deng KD., Jiang CG., Diao QY. Effect of dietarypolymer-coated urea and sodium bentonite on digestibility rumen fermentation, and microbial protein yield in sheep fed high levels of corn stalk. Livestock Science 2013; 157: 141-150.

Demeyer DI., Meulenmeester M., de Graeve K., Gupta GW. Effect of fungal treatment of nutritive value of straw. Med. Fac. Landbouww Rijksuniv. Gent 1988; 53: 1811-1819.

Denek H., Deniz S. Ruminant beslemede yaygın olarak kullanılan kimi kaba yemlerin sindirilebilirlik ve metabolik enerji düzeylerinin in-vitro metotlarla belirlenmesi. Turk J. Vet. Anim. Sci. 2004; 28: 115-122.

Eriksson KEL., Blanchette RA., Ander P. Microbial and enzymatic degradation of wood and wood components. Springer-Verlag. New York. 1990.

Fahmy STM., Klopfenstein TJ. Treatment with different chemicals andtheir effects on the digestibility of maize stalks: 2. Intake and in vivodigestibility as affected by chemical treatment and monensinsupplementation. Anim. Feed Sci. Technol. 1994; 45: 309-316.

Fazaeli H., Mahmodzadeh H., Azizi A., Jelan ZA., Liang JB., Rouzbehan Y., Osman A. Nutritive value of wheat straw treated with pleurotus fungi. Asian-Aust. J. Anim. Sci., 2004; 12(17): 1681-1688. 
Gültepe EE., Bayram İ. Bitkisel ve endüstriyel atıkların ruminant beslemede etkin kullanımının hayvan verimi üzerine etkileri. Çerçi İH, editör. Rekabet Edebilir Ruminant Yetiştiriciliğinde Yem ve Besleme Yönetiminin Önemi. 1. Bask1. Ankara: Türkiye Klinikleri; 2019. p.14-21.

Hadibarata T., Khudhair AB., Salim MR. Breakdown products in the metabolic pathway of anthracene degradation by a ligninolytic fungus Polyporus sp. S133. Water Air Soil Pollut 2012; 223: 2201-2208.

Jalc D., Siroka P., Ceresnakova Z. Effect of six species of white-rot basidiomycetes on the chemical composition and rumen degradability of wheat straw. Journal General Applied Micobiology. 1997; 43: 133-137.

Karimi AH., Acda SP., Capitan SS., Laurena AC., Tambalo FZ., Angeles AA., Loresco MM., Aychocho IO., Sevilla CC. In-situ cattle rumen degradability of urea-molasses and cellulase treated rice straw. Annual Research \& Review in Biology 2014; 4(22): 3420-3428.

Karabulut A., Canbolat Ö. Yem değerlendirme ve analiz yöntemleri kitabı. Uludağ Üniversitesi. Ziraat Fakültesi 2005; Yayın No:2.05.048.0424.

Kutlu HR., Görgülü M., Baykal L., Özcan N., Büyükalaca S. Effect of Pleurotus Florida Inoculation or urea treatment on feeding value of wheat straw. Turkish Journal of Veterinary Animal Sciences 2000; 24: 169-175.

Ørskov ER., McDonald I. The estimation of protein degradability in the rumen from incubation measurements weighted according to rate of passage. Journalof Agriculturel Science Cambridge 1979; 92: 499-503.

Ma F., Wang J., Zeng Y., Yu H., Yang Y., Zhang X. Influence of the co-fungaltreatment with two white rot fungi on the lignocellulosic degradation andthermogravimetry of corn stover. Process Biochem. 2011; 46: 1767-1773.

McDonald L. A revised model for the estimation of protein degradability in the rumen. J. Agric. Sci. Camb. 1981; 96: 251-252.

Moon YH., Ok JU., Lee SJ., Ha JK., Lee SSA. Comparative study on the rumen microbial populations. hydrolytic enzyme activities and dry matter degradability between different species of ruminant. Animal Science Journal. 2010; 81: 642-647.

NRC. Nutrient Requirements of Sheep Sixth revised edition. National academy. Washington D.C. 1985

Okano K., Boonlue S., Suzuki Y. Effects of ammonium hydroxide treatment on the in vitro dry matter digestibility and gas production of wheat straw. sugarcane bagasse medium and konara oak rotted by edible basidiomycetes. Animal Science Journal 2005; 76: 147-152.

Rahman MM., Lourenc OM., Hassim HA., Baars JJP., Sonnenberg ASM., Cone JW., De Boever J., Fievez V. Improving ruminal degradability of oil palmfronds using white rot fungi. Anim. Feed Sci. Technol. 2011; 169: 157-166. 
Reid ID. Solid state fermentation for biological delignification. Enzyme and Microbial Technology 1989; 11: 786-803.

Ribeiro JMCR. Nutritive value of treated straw. In: Tisserand J.-L. (ed.). Les pailles dans l'alimentation des ruminants en zone méditerranéenne. Zaragoza: CIHEAM. 1994; p. 79-95 (Options Méditerranéennes: Série B. Etudes et Recherches; n. 6).

Sharma RK., Arora DS. Fungal degradation of lignocellulosic residues: an aspect of improved nutritive quality. Critical Reviews Microbiology 2013; 1-9.

Shrivastava B., Thakur S., Khasa YP., Gupte A., Puniya AK., Kuhad RC. White-rot fungal conversion of wheat straw to energy rich cattlefeed. Biodegradation 2011; 22: 823-831.

Singh D., Zeng J., Laskar DD., Deobald L., Hiscox WC., Chen S. Investigation of wheat straw biodegradation by Phanerochaete chrysosporium. Biomass and Bioenergy 2011; 35: 10301040.

SPSS. SPSS Base 19. 0 User Guide. SPSS Inc. Chicago. IL. USA. 2010.

Sundstøl F., Owen E. Straw and other fibrous by-products as feed. Dev. Anim. Vet. Sci 1984; 604.

Susmel P., Stefanon B., Mills CR., Spenghero M. Rumen degradability of organic matter. nitrogen and fibre fractions forages. Animal Production 1990; 51: 515-526.

Talaei A., Karimi A., Thévenon MF. Influence of heat treatment medium on fungal resistance of beech wood. The International Research Group On Wood Protection. Proceedings IRG Annual Meeting (ISSN 2000-8953). Paper prepared for the $44^{\text {th }}$ Annual Meeting. 16-20 June 2013. Stockholm. Sweden.

Tao L., Zhang LX., Tu Y., Zhang NF., Si BW., Ma T., Diao QY. (Improving the in situ ruminal degradability of maize stalk usingfungal inoculants in dorper $\times$ thin-tailed han crossbred ewes. Small Ruminant Research 2016; 144: 119-125.

Turgut L., Yanar M. In-situ dry matter and crude protein degradation kinetics of some forages in Eastern Turkey. Small Ruminant Research 2004; 52: 217-222.

Turgut L. Kimyasal muameleye tabi tutulan buğday ve arpa samanlarının rumende parçalanabilirliklerinin belirlenmesi. OMÜ Ziraat Fakültesi Dergisi 2008; 23, 3: 183-189.

Tuyen VD., Cone JW., Baars JJP., Sonnenberg ASM., Hendriks WH. Fungal strain and incubation period affect chemical composition and nutrient availability of wheat straw for Rumen fermentation. Bioresource Technology 2012; 111: 336-342.

Valmaseda M., Almendros G., Martinez AT. Substrate dependent degradation patterns in-situ the decay of wheat straw and beech wood by ligninolytic fungi. Applied Microbiology Biotechnology 1990; 33: 481-484.

Van Soest PJ., Robertson JD., Lewis BA. Methods for dietary fiber. neutral detergent fiber and nonstarch polysaccharide in relation to animal nutrition. Journal of Dairy Science 1991; 74: 35833597. 
Yao W., Nokes SE. Phanerochaete chrysosporium pretreatment ofbiomass to enhance solvent production in subsequent bacterial solid-substratecultivation. Biomass Bioenergy 2014; 62: 100-107.

Yıldırım N., Yıldız A. Pleurotus eryngii suşlarının lignoselülozik soya saplarını biyodönüştürme etkinlikleri. Ekoloji 2010; 19(76): 88-94.

Zadrazil F., Uniya AK. Studies on the effect of particle size on solid-state fermentation of sugarcane bagasse into animal feedusing white-rot fungi. Bioresource Technology 1995; 54: 85-87. 